\title{
THORNTHWAITE’S CLIMATE REGIONALIZATION FOR THE STATE OF TOCANTINS, BRAZIL
}

\author{
Fábio Henrique Morais de Souza ${ }^{1}$, Marcelo Ribeiro Viola ${ }^{2 *}$, Junior Cesar Avanzi ${ }^{3}$, Marcos Giongo ${ }^{4}$, Marcelo \\ Vieira Filho ${ }^{5}$ \\ 1*Universidade Federal do Tocantins, Programa de Pós-Graduação em Ciências Florestais e Ambientais, Gurupi, Tocantins, Brasil - e-mail \\ fhms17@hotmail.com \\ ${ }^{2}$ Universidade Federal de Lavras, Programa de Pós-Graduação em Recursos Hídricos, Lavras, Minas Gerais, Brasil - e-mail \\ marcelo.viola@ufla.br \\ ${ }^{3}$ Universidade Federal de Lavras, Programa de Pós-Graduação em Ciência do Solo, Lavras, Minas Gerais, Brasil - e-mail \\ junior.avanzi@ufla.br \\ ${ }^{4}$ Universidade Federal do Tocantins, Programa de Pós-Graduação em Ciências Florestais e Ambientais, Gurupi, Tocantins, Brasil - e-mail \\ giongo@uft.edu.br \\ ${ }^{5}$ Universidade Federal de Lavras, Programa de Pós-Graduação em Engenharia Ambiental, Lavras, Minas Gerais, Brasil - e-mail \\ marcelo.filho@ufla.br
}

Received on: 30/04/2018 - Accepted on: 14/02/2019

\begin{abstract}
Resumo
Regionalização climática de thornthwaite para o estado de Tocantins. O Estado do Tocantins encontra-se em franca expansão agrícola. Assim, estudos sobre regionalização climática são essenciais para a melhor compreensão e predição da variabilidade climatológica, subsidiando o planejamento agrícola e ambiental. Nesse contexto, objetivou-se aplicar a classificação climática de Thornthwaite e proceder à regionalização climática por meio de técnicas geoestatísticas, avaliando o desempenho dos interpoladores krigagem ordinária (KO) e cokrigagem (CK). Foram utilizados dados de 26 estações meteorológicas localizadas no Estado do Tocantins e entorno. O balanço hídrico climatológico permitiu obter as variáveis de interesse para regionalização climática, que foram mapeadas por técnicas geoestatísticas. Os resultados da validação cruzada mostraram que a krigagem ordinária e a cokrigagem apresentaram desempenho satisfatório. Os modelos de semivariograma esférico e exponencial obtiveram melhor desempenho em $40 \%$ das análises cada, enquanto que o gaussiano obteve em $20 \%$. A classificação de Thornthwaite aplicada ao Tocantins mostrou a presença dos climas Úmido $\left(B_{1}\right)$, Subúmido úmido $\left(C_{2}\right)$ e Subúmido Seco $\left(C_{1}\right)$, em três regiões climáticas específicas: B1 A'wa' (clima úmido, megatérmico, com moderada deficiência de água no inverno, e regime de eficiência de temperatura normal para o tipo climático megatérmico) na região oeste do estado do Tocantins; $\mathrm{C}_{2} \mathrm{~A}$ 'wa' (clima subúmido úmido, megatérmico, com moderada deficiência de água no inverno, e regime de eficiência de temperatura normal para o tipo climático megatérmico) na região central e estendendo-se de norte a sul; e C 1 A'w2a' (clima subúmido seco, megatérmico, com grande excesso de água no verão, e regime de eficiência de temperatura normal para o tipo climático megatérmico) no leste e nordeste.

Palavras-chave: classificação climática; geoestatística; clima; planejamento agrícola
\end{abstract}

\begin{abstract}
Tocantins State faces a large-scale agricultural expansion. Thus, climate studies are essential for a better understanding of climate variability supporting agricultural and environmental planning. In this context, this study applies the climatic classification of Thornthwaite and develops a climate regionalization through geostatistical techniques, assessing the performance of the interpolators ordinary kriging (OK) and cokriging (CK). Data from 26 weather stations located in Tocantins State and surroundings were used. The variables of interest to climate regionalization, obtained by the climatic water balance, were mapped by geostatistical techniques. The results of cross-validation showed that ordinary kriging and cokriging performed well. The spherical and exponential semivariogram models obtained the best fit in $40 \%$ of the analyzes each, and the gaussian in $20 \%$. The climatic classification of Thornthwaite applied to Tocantins State showed the presence of humid $\left(B_{1}\right)$, moist subhumid $\left(C_{2}\right)$, and dry subhumid $\left(C_{1}\right)$ climates. There were found three climatic regions: B 1 A'wa': Humid, megathermal, with moderate winter water deficiency, and a temperature efficiency regime normal to megathermal, occurring in the western region of the state; $\mathrm{C}_{2} \mathrm{~A}^{\prime}$ wa': Moist subhumid, megathermal, with moderate winter water deficiency, and a temperature efficiency regime normal to megathermal, occurring in the central region and extending from the north to the south of the state; and $\mathrm{C}_{1} \mathrm{~A}^{\prime} \mathrm{w}_{2} \mathrm{a}$ ': Dry subhumid, megathermal, with large summer water surplus, and a temperature efficiency regime normal to megathermal, in the east and northeast of the state.
\end{abstract}

Keywords: climate classification; geostatistics; climate; agricultural planning

FLORESTA, Curitiba, PR, v. 49, n. 4, p. 783 - 792, out/dez 2019. 


\section{INTRODUCTION}

Located in the Northern region of Brazil, the State of Tocantins is geographically in its central region, bordering the northeastern and midwestern regions (SEPLAN, 2012). Thus, the State sits in an important climate transition area, which requires detailed studies to map the different existing climatic regions.

The knowledge of regions with climate characteristics and homogeneous biogeographic is fundamental for providing information about the agricultural potentialities, ecological conditions, and the environment of a given place (ANDRADE JÚNIOR et al., 2005). Therefore, studies on climate regionalization can be widely used as an instrument of strategic agricultural planning in the context of water resources management (PASSOS et al., 2017).

Among the main climate classification methods are the Köppen and the Thornthwaite method. For the State of Tocantins, the Köppen method classifies the entire state as Aw - tropical climate with dry winter (ALVARES et al., 2014), being inadequate for climate assessment from the agricultural point of view. In this sense, the climate classification system proposed by Thornthwaite, which uses indexes based on climatological water balance (CWB), is shown to be more suitable for agricultural purposes, since this system is capable of separating mesoscale climates (APARECIDO et al., 2016; ROLIM; APARECIDO, 2016). However, this climate classification system has a complex symbology, which hinders its greater diffusion (ÁCS et al., 2014).

The surface meteorological monitoring is traditionally performed at weather stations. Interpolation techniques can be applied in GIS (Geographic Information System) for the regionalization of such information. In the Brazilian context, the following studies are highlighted: Alvares et al. (2014), for Brazil as a whole; Sá Jr. et al. (2012), for the State of Minas Gerais; Rolim and Aparecido (2016), for the State of São Paulo, among others. There are few climatological studies specifically addressing to the State of Tocantins. The Tocantins Atlas (SEPLAN, 2012) and the Tocantins Agroecological Zoning (EMBRAPA, 1999) are available. However, both studies present substantial differences in terms of zoned climatic regions. Hence, in the specific context of the State of Tocantins, for which the agricultural frontier is expanding, it is extremely necessary to develop studies aimed at defining the climatic zones most suitable for agricultural activities.

Among the spatial interpolation methods applied to the mapping of climatic variables, geostatistical techniques stand out. Based on the structuring of a semivariogram model for a given variable that has a spatial dependence structure, the geostatistical interpolator (kriging) enables nonbiased estimates with minimal estimation variance (GOOVAERTS, 1997). Studies addressing geostatistical techniques have been widely applied in the mapping of climate variables around the world, with good results. On this matter, the following studies are highlighted: Berndt et al. (2014) for Germany; Wang et al. (2014), for Canada; Mello et al. (2015), for Brazil; Frazier et al. (2016), for Hawaii; Burguera et al. (2018), for Spain; Crespi et al. (2018), for Italy; among others.

Thus, developing research on geostatistical interpolators for climate regionalization in GIS environment represents a promising tool for agricultural purposes. The possibility of applying databases densely sampled by remote sensing as the secondary variable in the cokriging procedure is a promising option in the search for better interpolation results. This is relevant especially in regions with low density of weather stations, e.g. the Northern region of Brazil.

In this context, we performed the climatic regionalization of Thornthwaite through the geostatistical interpolators ordinary kriging and cokriging for the State of Tocantins, aiming to identify the climatic regions occurring with in the state and their spatial variability.

\section{MATERIALS AND METHODS}

The studied area corresponds to the State of Tocantins, located between parallels $5^{\circ} 10^{\prime}$ ' $06^{\prime \prime}$ and $13^{\circ} 27^{\prime}$ 59" South, and meridians $45^{\circ} 44^{\prime} 46^{\prime \prime}$ and $50^{\circ} 44^{\prime} 33$ " West, with an area of 277,621 km², representing $3.26 \%$ of the Brazilian territory and $7.2 \%$ of the northern region (SEPLAN, 2012).

Its territory is inserted in the Legal Amazon, with occurrence of the Amazon biome in 9\% of the state's area. The Cerrado biome occupies about $91 \%$ of the state's area (SEPLAN, 2012). The average annual air temperature is between $25^{\circ} \mathrm{C}$ and $29^{\circ} \mathrm{C}$, with maximum monthly temperatures of $35^{\circ} \mathrm{C}$ in September, and absolute maximum temperature around $42{ }^{\circ} \mathrm{C}$. Minimum temperatures occur in July, with monthly averages of $15{ }^{\circ} \mathrm{C}$ and absolute minimum of $8{ }^{\circ} \mathrm{C}$. Thermal amplitude between the maximum and minimum averages is $14{ }^{\circ} \mathrm{C}$, and annual average rainfall ranges from $1,200 \mathrm{~mm}$ to $2,100 \mathrm{~mm}$ (SEPLAN, 2012).

We used monthly data of climatic elements from 26 weather stations located in the southern hemisphere, belonging to the Brazilian National Institute of Meteorology (INMET). These data are present in the Climate Normals (1961-1990) published by INMET (1992). 
The study considered stations near to the State of Tocantins aiming at a better description of the conditions in nearby areas. The location of the weather stations used is shown in Figure 1.

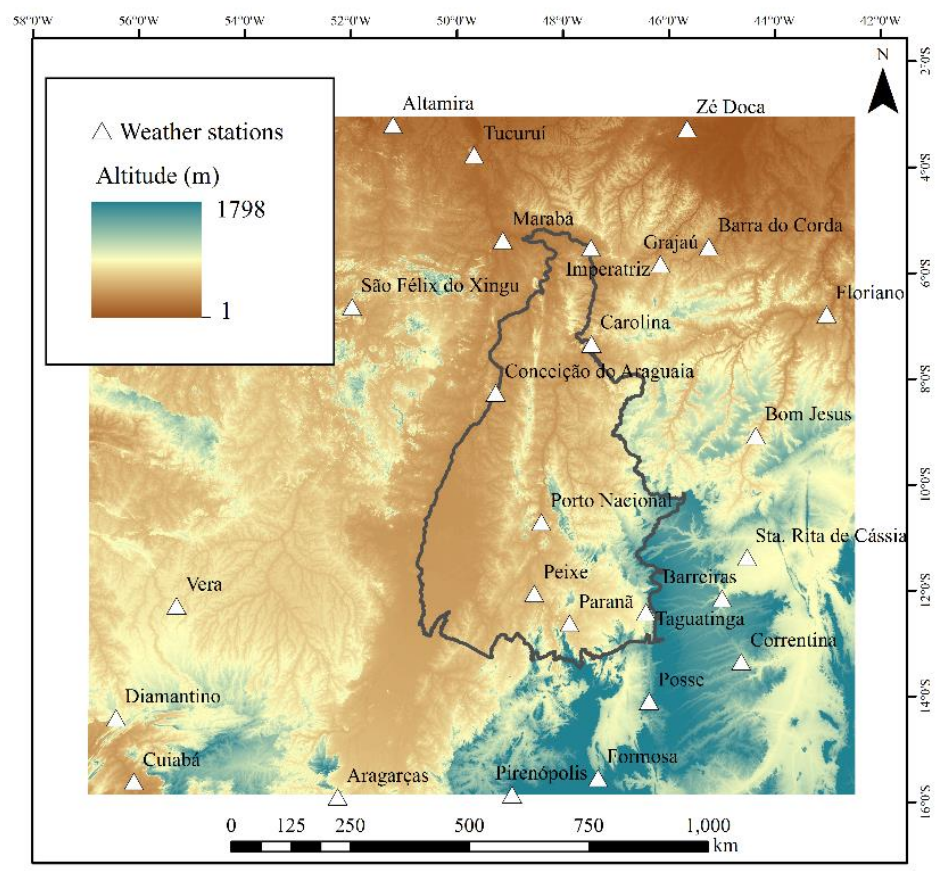

Figura 1. Localização das estações meteorológicas do INMET utilizadas neste trabalho, modelo digital de elevação SRTM (https://earthexplorer.usgs.gov/) e inserção do Estado do Tocantins

Figure 1. Location of the INMET weather stations used in this study, SRTM (https://earthexplorer.usgs.gov/) digital elevation model, and border line of the Tocantins State

For the elaboration of the climatological water balance (CWB), monthly average data of rainfall and temperature were used. The entire climatological water balance and climatic classification procedure were developed according to Thornthwaite and Mather revised method described by Vianello and Alves (2012). Having the CWB of each locality, the annual totals of potential evapotranspiration (PET), water deficiency (DEF), and water surplus (SUR) were used to calculate the following climate indexes: aridity $\left(\mathrm{I}_{\mathrm{a}}\right)$, humidity $\left(\mathrm{I}_{\mathrm{h}}\right)$, and moisture $\left(\mathrm{I}_{\mathrm{m}}\right)$ (modified), as well as the summer concentration potential evapotranspiration (SET), using the following equations:

$$
\begin{gathered}
I_{h}=(S U R / P E T) \times 100 \\
I_{a}=(D E F / P E T) \times 100 \\
I_{m}=I_{h}-I_{a} \\
S E T=\left(\sum \operatorname{PET}(\text { dec }+j a n+f e b) / P E T(\text { annual })\right) \times 100
\end{gathered}
$$

Climate types were defined based on the modified moisture index $\left(\mathrm{I}_{\mathrm{m}}\right)$, as shown in Table 1. Climate subdivisions were based on the aridity index $\left(\mathrm{I}_{\mathrm{a}}\right)$, humidity index $\left(\mathrm{I}_{\mathrm{h}}\right)$, and thermal efficiency index $\left(\mathrm{I}_{\mathrm{t}}\right.$ or annual PET), according to Tables 2 and 3.

Tabela 1. Classificação climática revisada de Thornthwaite e Mather (ICRISAT, 1980)

Table 1. Revised Thornthwaite and Mather classification (ICRISAT, 1980)

\begin{tabular}{cccc}
\hline Climate Types & Moisture Index $\left(\mathrm{I}_{\mathrm{m}}\right)$ & Climate Types & Moisture Index $\left(\mathrm{I}_{\mathrm{m}}\right)$ \\
\hline $\mathrm{A}-$ perhumid & $\mathrm{I}_{\mathrm{m}} \geq 100$ & $\mathrm{C}_{2}-$ moist subhumid & $0 \leq \mathrm{I}_{\mathrm{m}}<20$ \\
$\mathrm{~B}_{4}-$ humid & $80 \leq \mathrm{I}_{\mathrm{m}}<100$ & $\mathrm{C}_{1}-$ dry subhumid & $-33.3 \leq \mathrm{I}_{\mathrm{m}}<0$ \\
$\mathrm{~B}_{3}-$ humid & $60 \leq \mathrm{I}_{\mathrm{m}}<80$ & $\mathrm{D}-$ semi-arid & $-66.7 \leq \mathrm{I}_{\mathrm{m}}<-33.3$ \\
$\mathrm{~B}_{2}-$ humid & $40 \leq \mathrm{I}_{\mathrm{m}}<60$ & $\mathrm{E}-$ arid & $-100 \leq \mathrm{I}_{\mathrm{m}}<-66.7$ \\
$\mathrm{~B}_{1}-$ humid & $20 \leq \mathrm{I}_{\mathrm{m}}<40$ & & \\
\hline
\end{tabular}

FLORESTA, Curitiba, PR, v. 49, n. 4, p. 783 - 792, out/dez 2019. 
Tabela 2. Subdivisão da classificação climática segundo Thornthwaite (1948), baseada no índice de aridez $\left(\mathrm{I}_{\mathrm{a}}\right)$ e índice hídrico $\left(\mathrm{I}_{\mathrm{h}}\right)$

Table 2. Subdivision of climate types based on the aridity index $\left(\mathrm{I}_{\mathrm{a}}\right)$ and humidity index $\left(\mathrm{I}_{\mathrm{h}}\right)$, according to Thornthwaite (1948)

\begin{tabular}{|c|c|c|c|}
\hline $\begin{array}{c}\text { Humid climates } \\
\left(\mathbf{A}, B_{4}, B_{3}, B_{2}, B_{1}, C_{2}\right)\end{array}$ & $\left(\mathrm{I}_{\mathrm{a}}\right)$ & $\begin{array}{c}\text { Dry climates } \\
(\mathrm{C} 1, \mathrm{D}, \mathrm{E})\end{array}$ & $\left(\mathrm{I}_{\mathrm{h}}\right)$ \\
\hline $\begin{array}{l}\mathrm{r}-\text { little or no water } \\
\text { deficiency }\end{array}$ & $0 \leq \mathrm{I}_{\mathrm{a}}<16.7$ & $\begin{array}{l}\mathrm{d} \text { - little or no water } \\
\text { surplus }\end{array}$ & $0 \leq \mathrm{I}_{\mathrm{h}}<10$ \\
\hline $\begin{array}{l}\mathrm{s}-\text { moderate summer } \\
\text { water deficiency }\end{array}$ & $16.7 \leq \mathrm{I}_{\mathrm{a}}<33.3$ & $\begin{array}{l}\mathrm{s}-\text { moderate winter } \\
\text { water surplus }\end{array}$ & $10 \leq \mathrm{I}_{\mathrm{h}}<20$ \\
\hline $\begin{array}{l}\mathrm{w}-\text { moderate winter } \\
\text { water deficiency }\end{array}$ & $16.7 \leq \mathrm{I}_{\mathrm{a}}<33.3$ & $\begin{array}{l}\text { w - moderate summer } \\
\text { water surplus }\end{array}$ & $10 \leq \mathrm{I}_{\mathrm{h}}<20$ \\
\hline $\begin{array}{l}\mathrm{s}_{2}-\text { large summer water } \\
\text { deficiency }\end{array}$ & $\mathrm{I}_{\mathrm{a}} \geq 33.3$ & $\begin{array}{l}\mathrm{s}_{2}-\text { large winter water } \\
\text { surplus }\end{array}$ & $\mathrm{I}_{\mathrm{h}} \geq 20$ \\
\hline $\begin{array}{l}\mathrm{w}_{2}-\text { large winter water } \\
\text { deficiency }\end{array}$ & $\mathrm{I}_{\mathrm{a}} \geq 33.3$ & $\begin{array}{l}\mathrm{w}_{2}-\text { large summer water } \\
\text { surplus }\end{array}$ & $\mathrm{I}_{\mathrm{h}} \geq 20$ \\
\hline
\end{tabular}

Tabela 3. Subdivisão da classificação climática segundo Thornthwaite (1948), baseados no índice térmico (PET anual) e na concentração da evapotranspiração ocorrente no verão (ETV)

Table 3. Subdivision of climate types according to Thornthwaite (1948), based on the thermal efficiency index (annual PET) and summer concentration of annual evapotranspiration (SET)

\begin{tabular}{|c|c|c|c|}
\hline Climate Types & Annual PET (mm) & Climate Subtype & SET (\%) \\
\hline$A^{\prime}$ - megathermal & $\mathrm{PET} \geq 1,140$ & $a^{\prime}$ & SET $<48.0$ \\
\hline $\mathrm{B}^{\prime}{ }_{4}-$ mesothermal & $1,140>\mathrm{PET} \geq 997$ & $b^{\prime}{ }_{4}$ & $48.0 \leq \mathrm{SET}<51.9$ \\
\hline $\mathrm{B}_{3}{ }_{3}-$ mesothermal & $997>\mathrm{PET} \geq 855$ & $b_{3}^{\prime}$ & $51.9 \leq \mathrm{SET}<56.3$ \\
\hline $\mathrm{B}^{\prime}{ }_{2}-$ mesothermal & $855>\mathrm{PET} \geq 712$ & $b_{2}^{\prime}$ & $56.3 \leq \mathrm{SET}<61.6$ \\
\hline $\mathrm{B}^{\prime}{ }_{1}-$ mesothermal & $712>\mathrm{PET} \geq 570$ & $b^{\prime}{ }_{1}$ & $61.6 \leq \mathrm{SET}<68.0$ \\
\hline $\mathrm{C}_{2}{ }_{2}$ - microthermal & $570>\mathrm{PET} \geq 427$ & $c^{\prime}{ }_{2}$ & $68.0 \leq \mathrm{SET}<76.3$ \\
\hline $\mathrm{C}^{\prime}{ }_{1}$ - microthermal & $427>\mathrm{PET} \geq 285$ & $c^{\prime}{ }_{1}$ & $76.3 \leq \mathrm{SET}<88.0$ \\
\hline$D^{\prime}-$ tundra & $285>\mathrm{PET} \geq 142$ & d' & $\mathrm{SET} \geq 88.0$ \\
\hline$E^{\prime}-$ frost & $\mathrm{PET}<1 \overline{4} 2$ & & \\
\hline
\end{tabular}

Spherical, exponential, and Gaussian semivariogram models were evaluated for spatialization of climatic indexes. The choice of the semivariogram model is crucial for the quality of the mapping of study variables. The degree of spatial dependence (DSD), was calculated -the ratio between the structural variance or contribution (SV) and the sill $(\mathrm{NU}+\mathrm{SV})$ - was calculated to verify the existence of a spatial dependence structure of the adjusted models. The degree of spatial dependence is classified as follows: weak dependency for values less than $25 \%$; moderate dependency, values between 25\% and 75\%; and strong dependency for values greater than $75 \%$ (CAMBARDELLA et al., 1994).

To evaluate which semivariogram model performed better among the three evaluated, the cross-validation technique was applied. Cross-validation consists in removing data from the sample dataset, followed by estimating the variable under study for this position using the remaining samples. Thus, using the observed values and those calculated by cross-validation, statistical coefficients were computed to evaluate which semivariogram model produced the best result for each of the two interpolators studied (ordinary kriging (OK) and cokriging (CK)). The two generated statistical coefficients applied were Bias and Mean Absolute Percentage Error (MAPE). The first one quantifies the occurrence of a trend for overestimation or underestimation. Meanwhile, a low MAPE value corresponds to greater the similarity observed value and the one calculated by cross-validation (LIMA; ALVES, 2009). The semivariogram model with the lowest MAPE value was selected to map the climatic indexes.

Climatic regionalization was performed using an extension of ArcMap, ArcGIS9.2® (ESRI, 2004) a wellknown GIS (Geographic Information System) environment. For cokriging, the altitude extracted from the Digital Elevation Model (DEM) Shuttle Radar Topography Mission (SRTM) (FARR et al., 2007), with spatial resolution of 90 meters, was adopted as secondary variable.

Thus, surface maps were generated by the OK and CK methods for the climatic indexes $\mathrm{I}_{\mathrm{h}}, \mathrm{I}_{\mathrm{a}}, \mathrm{I}_{\mathrm{m}}$, PET and SET. Subsequently, these maps were reclassified, considering the amplitudes described in Tables 1, 2 , and 3. Finally, the climate regionalization map was obtained by overlapping the maps of climatic indexes. Based on the moisture index $\left(\mathrm{I}_{\mathrm{m}}\right)$, humid (A, B4, B3, B2, B1, and C2), or dry (C1, D, and E) climates were distinguished. Climate 
subtypes associated with humid climates were then defined based on $\mathrm{I}_{\mathrm{a}}$, PET, and SET, while those associated with dry climates were defined based on $\mathrm{I}_{\mathrm{h}}$, PET, and SET. The results obtained were then compared with preexisting results generated by Embrapa (1999) and Seplan (2012).

\section{RESULTS}

The Thornthwaite and Mather (1955) climatological water balance was developed for each location, and the value of $100 \mathrm{~mm}$ was established for maximum available water capacity (AWC). Table 4 shows the semivariogram model selected for the spatialization of each variable under study. Among the lowest MAPE values, the exponential and spherical models stood out in $80 \%$ of the situations ( $40 \%$ in each case), while the gaussian model stood out in $20 \%$ of the cases (PET $(\mathrm{CK})$ and $\mathrm{I}_{\mathrm{m}}(\mathrm{OK})$ ). This highlights the importance of analyzing which semivariogram model is most appropriate for modeling the semivariance of each variable.

Tabela 4. Parâmetros do modelo de semivariograma (NU - efeito pepita, SV - variância estrutural, A - alcance) que apresentou menor erro médio percentual absoluto (MAPE), grau de dependência espacial (DSD) e BIAS para os índices climáticos PET (evapotranspiração potencial anual), SET (concentração da evapotranspiração potencial anual no verão), $\mathrm{I}_{\mathrm{a}}$ (índice de aridez), $\mathrm{I}_{\mathrm{m}}$ (índice de umidade) e $\mathrm{I}_{\mathrm{h}}$ (índice hídrico) por krigagem ordinária (KO) e cokrigagem (CK)

Table 4. Parameters of the semivariogram model (NU - nugget, SV - structural variance, A - range) with the lowest value of mean absolute percentage error (MAPE), degree of spatial dependence (DSD) and BIAS for climate indexes PET (annual potential evapotranspiration), SET (summer concentration of annual evapotranspiration), $\mathrm{I}_{\mathrm{a}}$ (aridity index), $\mathrm{I}_{\mathrm{m}}$ (moisture index), and $\mathrm{I}_{\mathrm{h}}$ (humidity index) by ordinary kriging $(\mathrm{OK})$ and cokriging $(\mathrm{CK})$

\begin{tabular}{cccccccc}
\hline Climatic Index & Model & NU & SV & A (km) & BIAS (\%) & MAPE (\%) & DSD (\%) \\
\hline PET $($ KO) & spherical & 0 & 36513 & 1,054 & 0.3 & 4.8 & 100 \\
PET $(\mathrm{CK})$ & gaussian & 3944 & 34977 & 943 & 0.2 & 4.7 & 91 \\
SET $(\mathrm{KO})$ & exponential & 1.7 & 1.2 & 2,069 & 0.0 & 4.5 & 63 \\
SET $(\mathrm{CK})$ & exponential & 0 & 6 & 2,069 & 0.1 & 4.3 & 100 \\
$\mathrm{I}_{\mathrm{a}}(\mathrm{OK})$ & spherical & 0 & 81 & 1,507 & 4.4 & 15.0 & 100 \\
$\mathrm{I}_{\mathrm{a}}(\mathrm{CK})$ & spherical & 17 & 111 & 2,069 & 4.4 & 15.3 & 84.6 \\
$\mathrm{I}_{\mathrm{m}}(\mathrm{OK})$ & gaussian & 190 & 845 & 936 & -24.5 & 41.3 & 81,7 \\
$\mathrm{I}_{\mathrm{m}}(\mathrm{CK})$ & exponential & 0 & 1446 & 2,069 & -22.0 & 58.0 & 100 \\
$\mathrm{I}_{\mathrm{h}}(\mathrm{OK})$ & exponential & 0 & 928 & 1,826 & 15.6 & 36.3 & 100 \\
$\mathrm{I}_{\mathrm{h}}(\mathrm{CK})$ & spherical & 86 & 1621 & 2,069 & -20.7 & 54.6 & 95 \\
\hline
\end{tabular}

The BIAS value corresponds to the percentage of climatic index bias calculated by the interpolators. Positive and negative values indicate a trend for underestimation and overestimation, respectively. For the variables PET, SET, and $I_{a}$, BIAS values below 5\% were obtained, while for the variables $I_{m}$ and $I_{h}$, these values were below $25 \%$. Thus, most estimates showed good accuracy, denoting that the parameters were properly adjusted. In this sense, for the indexes PET, SET and $I_{a}$, positive BIAS values were obtained, denoting an underestimation trend, while for $\mathrm{I}_{\mathrm{m}}$ an overestimation trend was obtained by both interpolators.

Comparing the cross-validation results obtained by interpolators $\mathrm{OK}$ and $\mathrm{CK}$, the second showed better MAPE and BIAS results only for PET. Therefore, the use of the digital elevation model as a secondary variable in cokriging interpolator of climatic indexes did not result in improvements when compared to ordinary kriging. This can be explained by the poor correlation between altitude and climatic indexes. The correlation coefficient (r) between climatic indexes and altitude was weak $(|\mathrm{r}|<0.5)$ for SET, $\mathrm{I}_{\mathrm{a}}, \mathrm{I}_{\mathrm{m}}$, and $\mathrm{I}_{\mathrm{h}}$, and strong $(|\mathrm{r}|>0.8)$ for PET.

The degree of spatial dependence (DSD) of climatic indexes was classified as strong spatial dependence structure (DSD>75\%), except for SET by interpolator OK, for which DSD was classified as moderate. Another important aspect concerns the high range (A) of the spatial dependence structure obtained for the climatic indexes by both interpolators, over $936 \mathrm{~km}$ and $943 \mathrm{~km}$ for OK and CK, respectively. Thus, it is clear that the climatic indexes associated with the Thornthwaite classification studied for the State of Tocantins show a comprehensive spatial dependence structure, a situation in which good estimates are expected with the application of geostatistical techniques.

Figure 2 shows the maps of climatic indexes PET, SET, $I_{a}, I_{h}$, and $I_{m}$ obtained by interpolators OK and CK for Tocantins State.

FLORESTA, Curitiba, PR, v. 49, n. 4, p. 783 - 792, out/dez 2019. 


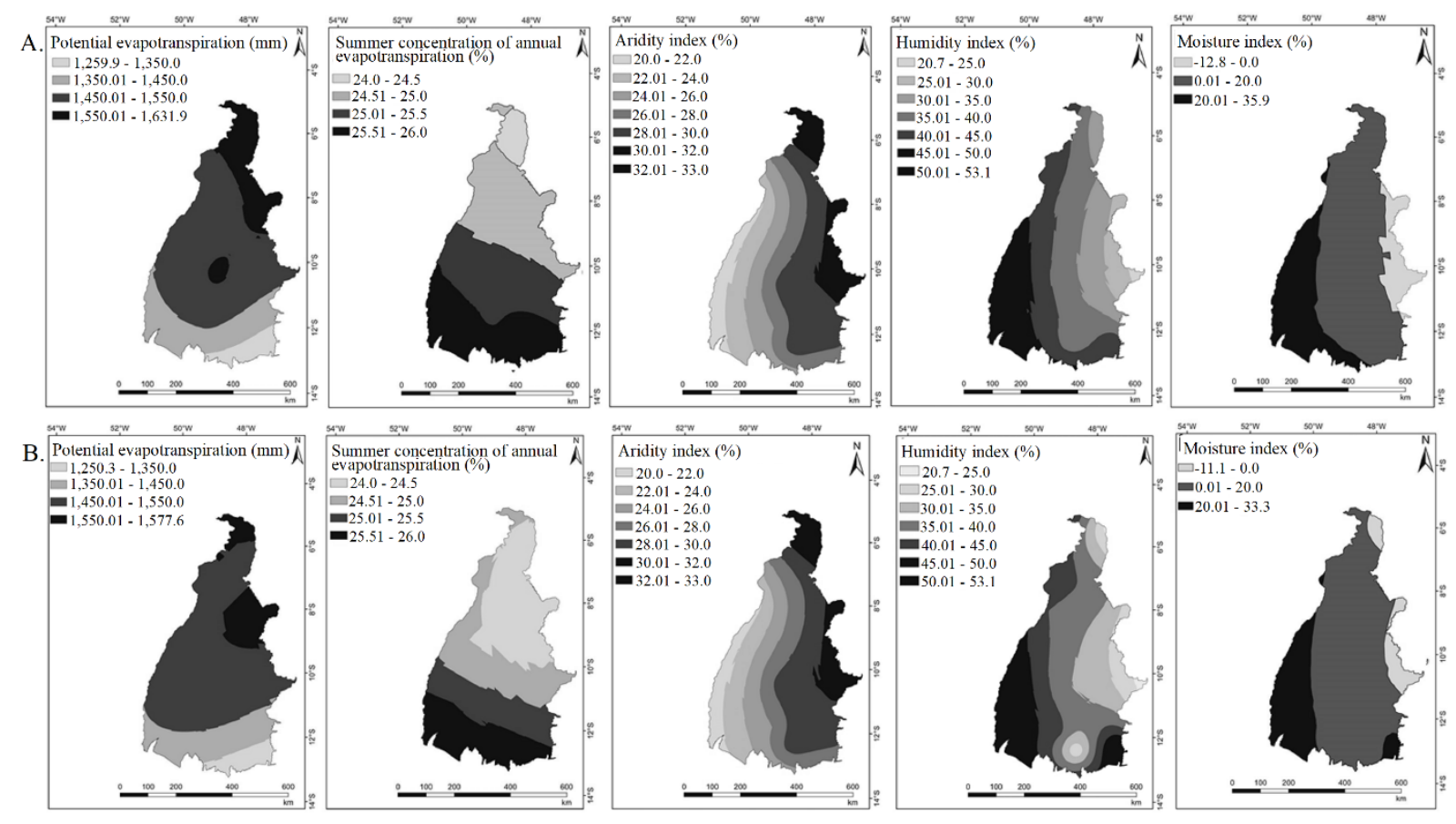

Figura 2. Mapas de evapotranspiração potencial anual (PET), concentração da evaporação potencial anual ocorrente no verão $(\mathrm{SET})$, índice de aridez $\left(\mathrm{I}_{\mathrm{a}}\right)$, índice hídrico $\left(\mathrm{I}_{\mathrm{h}}\right)$ e índice de umidade $\left(\mathrm{I}_{\mathrm{u}}\right)$ obtidos por krigagem ordinária (A) e cokrigagem (B)

Figure 2. Maps of potential annual evapotranspiration (PET), summer concentration of potential evapotranspiration $(\mathrm{SET})$, aridity index $\left(\mathrm{I}_{\mathrm{a}}\right)$, humidity index $\left(\mathrm{I}_{\mathrm{h}}\right)$, and moisture index $\left(\mathrm{I}_{\mathrm{m}}\right)$ obtained by ordinary kriging $(\mathrm{A})$ and cokriging $(\mathrm{B})$

The potential annual evapotranspiration (PET), considered as thermal index in the Thornthwaite classification, presented maximum values of 1,632 $\mathrm{mm}(\mathrm{OK})$ and 1,578 $\mathrm{mm}(\mathrm{CK})$, with an increasing gradient from south to north. According to Thornthwaite's classification, the thermal index can range from subtype megathermal (A') to frost (E') (Table 3). By reclassifying the PET maps obtained by interpolators OK and CK, climate subtype megathermal (A') prevails for both for the whole Tocantins State, characterized by PET $\geq 1,440$ $\mathrm{mm}$.

The accumulated potential summer evapotranspiration (SET), in turn, varied between $24 \%$ and $26 \%$ for Tocantins State by both interpolators, with an increasing gradient from north to south. According to the Thornthwaite classification (Table 3), SET values lower than $48 \%$ indicate reduced variation in potential evapotranspiration throughout the year. It can be explained by the reduced amplitude of the thermal regime across the year in this region. In this approach, the entire State of Tocantins received a classification called a' (temperature efficiency regime normal to megathermal) in the Thornthwaite classification.

The aridity index $\left(\mathrm{I}_{\mathrm{a}}\right)$ showed that the water deficit, characteristic of the winter season in the Tocantins State (June to September), is equivalent to 20-33\% of the potential annual evapotranspiration throughout the state. Increasing values are observed from the west (near the Amazon biome) to the east (near the Caatinga biome), This index makes it possible to identify regions of the state where drought is most severe. Although there is a clear gradient for $I_{a}$, when reclassified according to Thorthwaite (Table 2), climate subtype w prevails in the State, characterizing the occurrence of moderate winter water deficiency.

Values ranging between $20.7 \%$ and $55.3 \%$ were obtained in the regionalization of the humidity index $\left(\mathrm{I}_{\mathrm{h}}\right)$. The Thornthwaite classification establishes climate subtypes centered on this index, ranging from regions with little or no water surplus $\left(0 \leq I_{h}<10\right)$ to regions with large water surplus $\left(I_{h} \geq 20\right)$. Thus, based on both interpolators, the annual water surplus, which is prevalent during the mainly months of the rainy season (December, January, and February), is rated $w_{2}$ (large summer water surplus) for the entire State of Tocantins (Table 2).

The moisture index, in turn, has shown to increase from east to west. Based on this index, and considering the class amplitude presented in Table 1 , the State of Tocantins shows two climate types classified as humid $\left(\mathrm{C}_{2}\right.$ and $\left.\mathrm{B}_{1}\right)$, and one classified as dry $\left(\mathrm{C}_{1}\right)$. Following is described the three identified climate types: a) $\mathrm{C}_{1}-$ dry 
subhumid $\left(-33.3 \leq \mathrm{I}_{\mathrm{m}}<0\right)$, in the extreme east of the state; b) $C_{2}-$ moist subhumid $\left(0 \leq \mathrm{I}_{\mathrm{m}}<20\right)$, in a central range, from north to south; and c) $B_{1}$ - humid $\left(20 \leq \mathrm{I}_{\mathrm{m}}<40\right)$, in the southwest of the state and in the far southeast on the map obtained by cokriging. This distinction with respect to the occurrence of the climate type in the extreme southeast of the state can be explained due to cokriging including a secondary variable (altitude) and due to differences in the semivariogram model and range. For cokriging, the exponential model with a range of 2,069 km was selected. For ordinary kriging, the gaussian model with a range of $936 \mathrm{~km}$ was used.

The climatic regionalization of Thornthwaite for Tocantins State was then obtained by overlapping the maps of climate indexes. Thus, zones with homogeneous climatic characteristics were obtained according to the Thornthwaite classification, through geostatistical interpolators OK and CK (Figure 3). The differences between the climate classification maps obtained by $\mathrm{OK}$ and $\mathrm{CK}$ are directly related to the $\mathrm{I}_{\mathrm{m}}$ maps, since for the other indexes similar results were obtained by both interpolators.

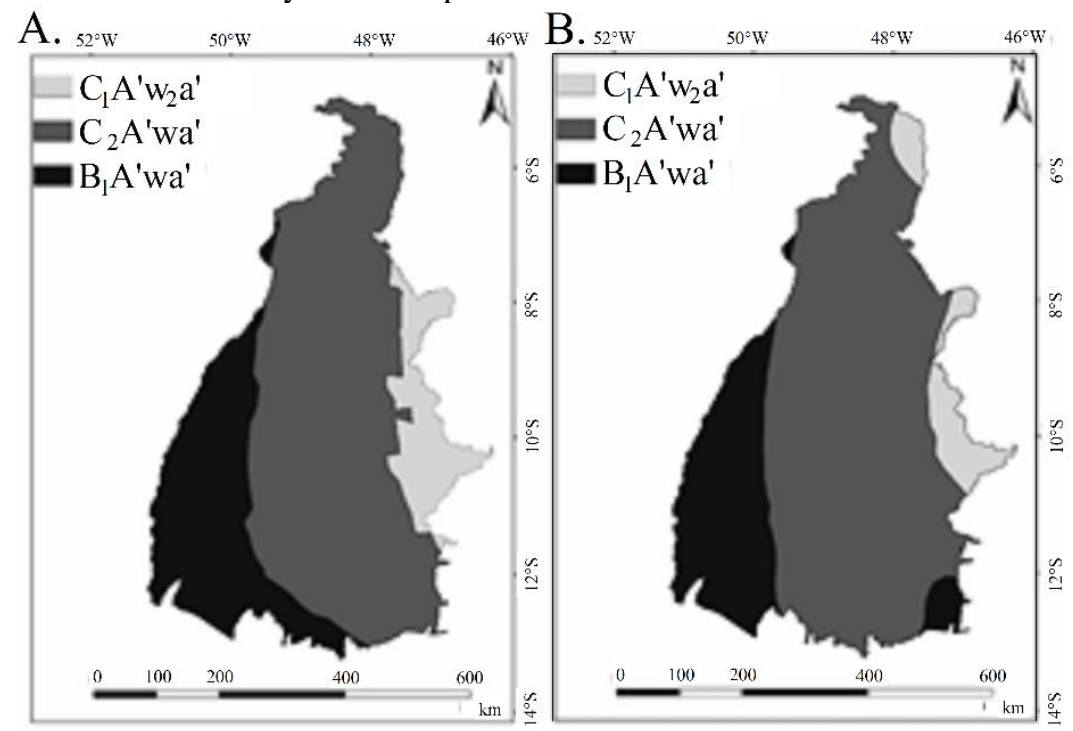

Figura 3. Mapas de regionalização climática do Estado do Tocantins obtidos por krigagem ordinária (A) e cokrigagem (B)

Figure 3. Climatic regionalization maps for Tocantins State, obtained by ordinary kriging (A) and cokriging (B)

Finally, the proposed Thornthwaite classification of the three identified homogeneous climatic regions obtained by the present study for the State of Tocantins are as follows: $\mathrm{C}_{1} \mathrm{~A}^{\prime} \mathrm{w}_{2} \mathrm{a}^{\prime}$ : Dry subhumid, megathermal, with large summer water surplus, and a temperature efficiency regime normal to megathermal; $\mathrm{C}_{2} \mathrm{~A}^{\prime}$ wa': Moist subhumid, megathermal, with moderate winter water deficiency, and a temperature efficiency regime normal to megathermal; and $\mathrm{B}_{1} \mathrm{~A}^{\prime}$ wa': Humid, megathermal, with moderate winter water deficiency, and a temperature efficiency regime normal to megathermal. The results of this study represents an important tool for agricultural and environmental planning in the State of Tocantins. For example, it may provide with valuable information for the identification of the best locations and most favorable seasons for non-irrigation agriculture.

\section{DISCUSSION}

Cross validation results showed good accuracy of geostatistical techniques (Table 4), indicating that the semivariograms were properly adjusted and did not produce biased estimates. It is also attested that the climatic indexes associated with the Thornthwaite classification present ample spatial dependence (Table 4), anticipating that usage of geostatistical techniques generates good estimates.

The predominant site of occurrence of climate type $\mathrm{C}_{1} \mathrm{~A}^{\prime} \mathrm{w}_{2} \mathrm{a}^{\prime}$ is in the extreme east of Tocantins, near the border with the States of Bahia, Piauí, and Maranhão, where Caatinga biome occurs. It is important to note that this climatic region showed a dry subhumid $\left(\mathrm{C}_{1}\right)$ climate type, due to the intense water deficit observed from April to September. Conversely, during the rainy season, especially between December and March, there is considerable water surplus, equivalent to up to $33 \%$ of the potential annual evapotranspiration. This situation characterizes climatic subtype $\mathrm{w}_{2}$, vis, summer with large water surplus. This finding shows better chances for successful development of agricultural activities during summer in this climatic region.

FLORESTA, Curitiba, PR, v. 49, n. 4, p. 783 - 792, out/dez 2019. 
Climate type $\mathrm{C}_{2} \mathrm{~A}^{\prime}$ wa' occurs in the central range of the state, from north to south. Examinating in more detail the climatological water balance of the weather stations, the region of climate $\mathrm{C}_{2}$ in the State of Tocantins is likely caused by the stations of Conceição do Araguaia - TO, Peixe - TO, Paranã - TO, Marabá - PA, and Carolina - MA.

The predominant site of occurrence of the climate type $\mathrm{B}_{1} \mathrm{~A}^{\prime}$ wa' was in western Tocantins, near the border with the states of Pará, Mato Grosso, and Goiás, near the Amazon biome. Looking at the climatological water balance of the stations located to the west of Tocantins State, it was observed that the stations of São Félix do Xingu - PA and Vera - MT showed a moisture index in the range of $20 \leq \mathrm{I}_{\mathrm{m}}<40$, influencing the region of influence of climate $B_{1}$ in the State of Tocantins. However, for the map obtained by cokriging, the climatic region $B_{1} A^{\prime}$ wa' also occurs in the extreme southeast, which can be justified by the moisture index value of Taguatinga - TO, which was $27.2 \%$. It is noteworthy that although the climate type is humid $\left(\mathrm{B}_{1}\right)$ due to intense water surplus during the rainy season (especially between December to March), there is a significant water deficiency in this climatic region during the winter months. This fact highlights possible difficulties for non-irrigation agriculture regarding the cultivation of two crops in the same year. Strategies such as crop-livestock integration may be pursued, where the implementation of the second crop (forage species) occurs even before the first crop is harvested, using the end of the rainy season to establish the forage.

The Tocantins Agroecological Zoning (EMBRAPA, 1999) and the Tocantins Atlas (SEPLAN, 2012) show different results compared to the present study for the Thornthwaite climatic regionalization in Tocantins State. Because the results of these studies, a discussion about the main differences observed is presented below.

In the southwest of the state, on Ilha do Bananal, the map of Embrapa shows the climate type $\mathrm{B}_{2} \mathrm{~A}^{\text {'ra'. }}$ On the other hand, for the same region, the present study and the Tocantins Atlas obtained the climate type B' 'A'wa'. Although both are considered humid climates, there are important differences between them. In the climate $\mathrm{B}_{2}$, the moisture index is higher than in $\mathrm{B}_{1}$, and in subtype $\mathrm{r}$ the aridity index is smaller than in w subtype. As there are no INMET weather stations with normal data for validation of regionalization in the region of Bananal Island and Cantão State Park, the good spatial dependence presented by the regionalized climate indexes in the present study (Table 4) is considered to provide a first approximation of the climate type of this region.

For the Bico do Papagaio region in the far north of Tocantins, Embrapa (1999) delimited a climate type ( $\mathrm{C}_{2} \mathrm{~A}^{\prime}$ ra'), while Seplan (2012) delimited a climate type $\mathrm{B}_{1} \mathrm{~A}^{\prime}$ wa'. Our kriging map results (Figure 3a) showed the climate type $\mathrm{C}_{2} \mathrm{~A}^{\prime}$ wa' was delimited for the entire region of Bico do Papagaio, which agrees with the classification obtained for the weather station of Marabá - PA. However, in the map generated by cokriging (Figure 3b), the eastern portion showed the climate type $\mathrm{C}_{1} \mathrm{~A}^{\prime} \mathrm{w}_{2} \mathrm{a}$ ', characterized as dry subhumid. This may be explained by the greater range of spatial dependence of cokriging for the moisture index (Table 4), and the consequent effect of the stations of Imperatriz - MA, Grajaú - MA, and Barra do Corda - MA, located to the east of the region and that present a dry climate type.

As seen, the results of the present study showed that the climate $\mathrm{C}_{2} \mathrm{~A}$ 'wa' takes place in the central range, from the north to the south of the state. Contrasting the maps of Seplan (2012) and Embrapa (1999) for this climate type, it is found that although the class is also present in those studies, its delimitation is different. Another important issue is that the present study mapped a climate type dry subhumid $\left(\mathrm{C}_{1}\right)$. This characterizes the influence of the weather stations located in the Northeastern Brazil. This type of climate does not occur in the study developed by Seplan (2012), while in the study by Embrapa (1999) it occurs in the extreme southeast of the state.

\section{CONCLUSIONS}

- Cross-validation made it possible to verify the good performance of the geostatistical interpolators ordinary kriging and cokriging, in the mapping of climatic indexes associated with the Thornthwaite classification in the State of Tocantins. Based on the applied statistical coefficients, it was not possible to verify a better performance by cokriging, which can be attributed to the correlation classified as weak between the primary (climatic indexes) and the secondary (altitude) variables, except for PET, for which a strong correlation was obtained.

- The Thornthwaite climatic regionalization applied to Tocantins State indicated the presence of the following climate types: a) $\mathrm{C}_{1} \mathrm{~A}^{\prime} \mathrm{w}_{2} \mathrm{a}^{\prime}$ (dry subhumid, megathermal, with large summer water surplus, and a temperature efficiency regime normal to megathermal) in the eastern end of Tocantins, near the border with the states of Bahia, Piauí, and Maranhão; b) $\mathrm{C}_{2} \mathrm{~A}^{\prime}$ wa' (moist subhumid, megathermal, with moderate winter water deficiency, and a temperature efficiency regime normal to megathermal) in the central range of the state, from north to south; and c) B $\mathrm{A}_{1}$ 'wa' (humid, megathermal, with moderate winter water deficiency, and a temperature efficiency regime normal to megathermal), especially in the southwest of the state, in the region of Bananal Island and Cantão State Park, near the borders with the states of Pará, Mato Grosso, and Goiás. 
- It is noteworthy to mention this Thornthwaite's Climate map is considered a first approximation due to the low availability of normal meteorological data series for vast regions of the State of Tocantins, such as the regions of Bananal Island and Jalapão. Thus, as the state meteorological database expands, future research should focus on the development of a more detailed climate regionalization.

\section{REFERENCES:}

ÁCS, F.; BREUER, H.; SKARBIT, N. Climate of Hungary in the twentieth century according to Feddema. Theoretical and Applied Climatology, v. 115, p. 1 - 9, 2014.

ALVARES, C.A.; STAPE, J.L.; SENTELHAS, P.C.; GONÇALVES, J.L.M.; SPAROVEK, G. Koppen's climate classification map for Brazil. Meteorologische Zeitschrift, v. 22, p. 711-728, 2014.

ANDRADE JÚNIOR, A. S.; BASTOS, E. A.; BARROS, A. H. C.; SILVA, C. O.; GOMES, A. A. N. Classificação climática e regionalização do semi-árido do Estado do Piauí sob cenários pluviométricos distintos. Revista Ciência Agronômica, Fortaleza, v. 36, n. 2, p. 143 - 151, 2005.

APARECIDO, L. E. O.; ROLIM, G. S.; RICHETTI, J.; SOUZA, P. S.: JOHANN, J. A. Köppen, Thornthwaite and Camargo climate classifications for climatic zoning in the State of Paraná, Brazil. Ciência e Agrotecnologia, Lavras, v. 40, n. 4, p. 405 - 417, 2016.

BERNDT, C.; RABIEI, E.; HABERLANDT, U. Geostatistical merging of rain gauge and radar data for high temporal resolutions and various station density scenarios. Journal of Hydrology. v. 508, p. 88 - 101, 2014.

BURGUERA, M. T.; BELGUERIA, S.; SERRANO, S. V.; MANETA, M. Optimal interpolation scheme to generate reference crop evapotranspiration. Journal of Hydrology. v. 560, p. 202 - 219, 2018.

CAMBARDELLA, C. A.; MOORMAN, T. B.; NOVAK, J. M.; PARKIN, T. B.; KERLEN, D. L.; TURCO, R. F.; KONOPKA, A. E. Field scale variability of soil properties in Central Iowa soils. Soil Science Society America Journal, Madison, v. 47, p. 1501 - 1511, 1994.

CRESPI, A.; BRUNETTI, M.; LENTINI, G.; MAUGERI, M. 1961-1990 high-resolution monthly precipitation climatologies for Italy. International Journal of Climatology. v. 38. p. 878 - 895, 2018.

EMBRAPA, 1999. Zoneamento Agroecológico do Estado do Tocantins. Embrapa Monitoramento por Satélite. 1999. Disponível em: < http://www.zaeto.cnpm.embrapa.br/clim.html> Aceso em 25 janeiro 2016.

ESRI - Environmental Systems Research Institute. ArcGIS 9: Getting started with ArcGIS. Redlands: 2004. 265p.

FARR, T. G.; PAUL A. R., EDWARD C., ROBERT C., RILEY D., SCOTT H., MICHAEL K., MIMI P., ERNESTO R. LADISLAV R., DAVID S., SCOTT S., SHIMADA J. The Shuttle Radar Topography Mission. Reviews of Geophysics, v. 45, 2007.

FRAZIER, A.G.; GIAMBELLUCA, T.W.; DIAZ, H.F.; NEEDHAM, H.L. Comparison of geostatistical approaches to spatially interpolate month-year rainfall for the Hawaiian Islands. International Journal of Climatology. v. 36, 1459 - 1470, 2016.

GOOVAERTS, P. Geostatistics for Natural Resources Evaluation. Oxford University Press, New York, 1997. $496 \mathrm{p}$.

ICRISAT - International Crops Research Institute for the Semi-arid Tropics. Climatic Classification: A Consultants' Meeting, 1980, ICRISAT Patancheru P.O., 1980, 153 p.

INMET - INSTITUTO NACIONAL DE METEOROLOGIA. Normais Climatológicas (1961-1990) - Ministério da Agricultura e Reforma Agrária; Secretaria Nacional de Irrigação; Departamento Nacional de Meteorologia/INMET - 1992.

LIMA, J. P. R.; ALVES, J. M. B. Um estudo de downscaling dinâmico de precipitação intrasazonal acoplado a modelo chuva-vazão na bacia hidrográfica alto-médio São Francisco. Revista Brasileira de Meteorologia, v. 24, n. 3, p. $323-338,2009$.

MELLO, C. R.; VIOLA, M. R.; OWENS, P. R.; MELLO, J. M.; BESKOW, S. Interpolation methods for improving the RUSLE R-factor mapping in Brazil. Journal of Soil and Water Conservation, v. 70, n. 3, p. 182 $-197,2015$.

FLORESTA, Curitiba, PR, v. 49, n. 4, p. 783 - 792, out/dez 2019.

Souza, F. H. M. et.al.

ISSN eletrônico 1982-4688

DOI: $10.5380 /$ rf.v49 i4.59188 
PASSOS, M. L. V.; ZAMBRZYCKI, G. C.; PEREIRA, R. S. Balanço hídrico climatológico e classificação climática para o município de Balsas-MA. Revista Scientia Agraria, Curitiba, v. 18, n. 1, p. 83 - 89, 2017.

ROLIM, G. S.; APARECIDO, L. E. O. Camargo, Köppen and Thornthwaite climate classification systems in defining climatical regions of the state of São Paulo, Brazil. Internation Journal of Climatology. v. 36, p. 636 643, 2016.

SÁ Jr., A.; CARVALHO, L.G.; SILVA, F.F.; ALVES, M.C. Application of the Koppen classification for climatic zoning in the state of Minas Gerais, Brazil. Theoretical and Applied Climatology. v. 108, p. 1 - 7, 2012.

SEPLAN. Secretária de Planejamento. Atlas do Tocantins: Subsídios ao Planejamento da Gestão Territorial. Superintendência de Planejamento e Gestão central de Políticas Públicas. Diretoria de Zoneamento EcológicoEconômico - DZE. Organizado por. BORGES, R. S. T.; DIAS, R. R.; SOUSA, P. A. B. (orgs). 6. ed. rev. atua. Palmas: Seplan, p.80. 2012.

THORNTHWAITE, C. V. An approach towards a rational classification of climate. Geographycal Review, London, n.38, p.55-94, 1948.

THORNTHWAITE, C. W.; MATHER, J. R. The water balance. Publications in Climatology. New Jersey: Drexel Institute of Technology, 1955.

VIANELLO, R. L.; ALVES, A. R. Meteorologia básica e aplicações. 2.ed. Viçosa: Ed. UFV, 2012. 460 p.

WANG, S.; HUANG, G. H.; LIN, Q. G.; ZHANG, H.; FAN, Y. R. Comparison of interpolation methods for estimating spatial distribution of precipitation in Ontario, Canada. International Journal of Climatology. v. 34, p. 3745 - 3751, 2014. 